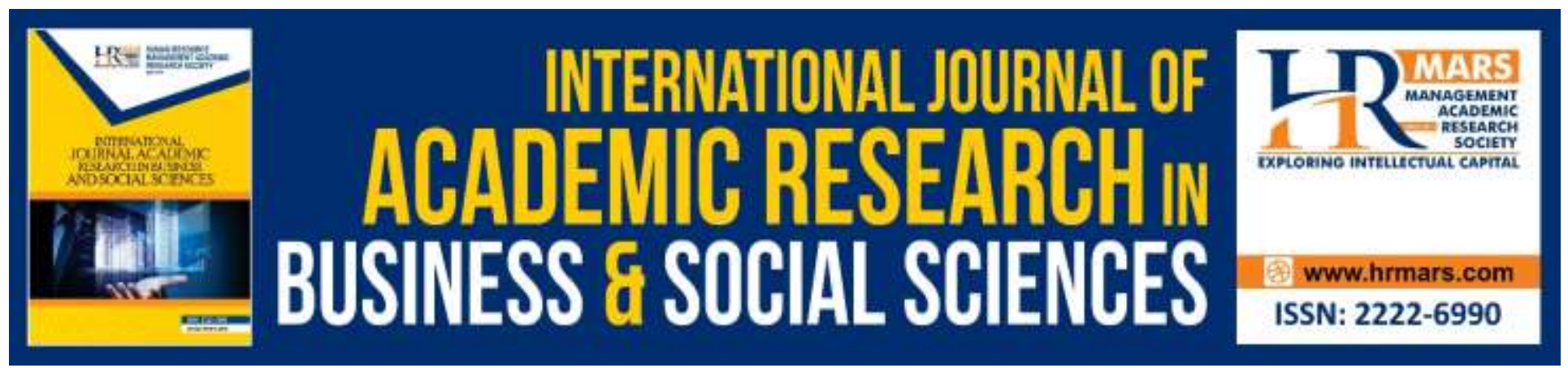

\title{
Measuring the Integrity of Young People Political Participation: Psychometric Analysis of Media Literacy
}

\section{Mohd Sufiean Hassan, Siti Nurshahidah Sah Allam, Abdul Mutalib Mohamed Azim, Maizatul Haizan Mahbob, Mohd Afendi Daud}

To Link this Article: http://dx.doi.org/10.6007/IJARBSS/v10-i2/6857

DOI:10.6007/IJARBSS/v10-i2/6857

Received: 11 January 2020, Revised: 22 January 2020, Accepted: 29 January 2020

Published Online: 08 February 2020

In-Text Citation: (Hassan et al., 2020)

To Cite this Article: Hassan, M. S., Allam, S. N. S., Azim, A. M. M., Mahbob, M. H., \& Daud, M. A. (2020). Measuring the Integrity of Young People Political Participation: Psychometric Analysis of Media Literacy. International Journal of Academic Research in Business and Social Sciences, 10(2), 12-33.

\section{Copyright: (C) 2020 The Author(s)}

Published by Human Resource Management Academic Research Society (www.hrmars.com)

This article is published under the Creative Commons Attribution (CC BY 4.0) license. Anyone may reproduce, distribute, translate and create derivative works of this article (for both commercial and non-commercial purposes), subject to full attribution to the original publication and authors. The full terms of this license may be seen at: http://creativecommons.org/licences/by/4.0/legalcode

Vol. 10, No. 2, 2020, Pg. 12 - 33

Full Terms \& Conditions of access and use can be found at http://hrmars.com/index.php/pages/detail/publication-ethics 


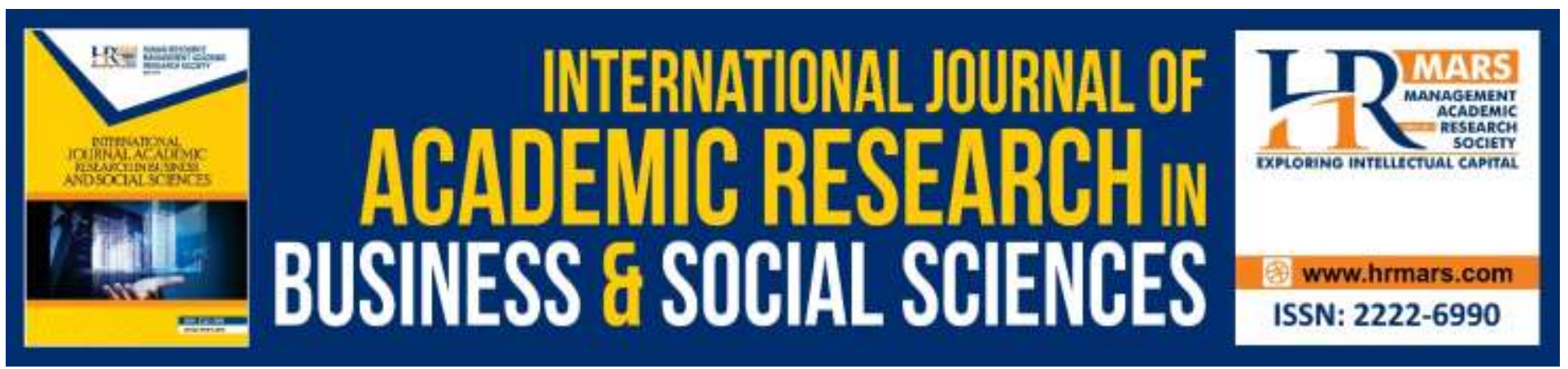

\title{
Measuring the Integrity of Young People Political Participation: Psychometric Analysis of Media Literacy
}

\author{
Mohd Sufiean Hassan \\ Kolej Universiti Islam Melaka (KUIM), Malaysia \\ Siti Nurshahidah Sah Allam \\ Universiti Teknologi MARA (UiTM), Melaka Branch, Malaysia \\ Abdul Mutalib Mohamed Azim \\ Kolej Universiti Islam Melaka (KUIM), Malaysia \\ Maizatul Haizan Mahbob \\ Universiti Kebangsaan Malaysia \\ Mohd Afendi Daud \\ Kolej Universiti Islam Melaka (KUIM), Malaysia
}

\begin{abstract}
Social media use claimed by political scientist influenced low integrity level of political participation among young people but aligning political movements with media literacy competency reported develop civic engagement from civic knowledge and drive to democracy participatory. It is essential for young people actively engage in political activities having media literacy competency in developing effective communicator. To test the value of integrity, a model of media literacy competency was tested among 388 students from four Higher Education Institutions in Melaka namely Universiti Teknologi MARA (UiTM) Melaka Branch, Universiti Teknikal Malaysia, Melaka, Multimedia University, (MMU) Melaka and Kolej Islam Universiti Melaka (KUIM). New media literacy scale instruments are developed from digital significance modeling and media literacy models to test the integrity of young people through Validation Factor Analysis (CFA) and the establishment of the CFA Model of Media Literacy Scale. Findings show that multi-dimensional model of media literacy has achieved good matching accuracy and achieves convergence validity based on significant relationship variables. This scale also achieves discriminatory and predictive validity that supports the Malay
\end{abstract}


version of psychometric features. This study directly contributes to the formation of media literacy scales and understanding of new media literacy that is important for the community, government and media practitioners in interpreting and understanding.

Keywords: Literacy, New Media, Integrity, Political Participation, Young People.

\section{Introduction}

The government's initiative to promote young people empowerment initiative stated in National Mission 2020 and directly mentioned by Ministry of Youth and Sports Malaysia in strategic thrust; empowering young people will be given the opportunity to determine the direction and planning of the organization. Youth leadership is nurtured in producing global youth and nurturing community. To drive national transformation agenda in line with in moral and cultural values, the execution of young people's integrity values can directly develop value of ethical leaders and reduce the tendency for low integrity participation especially in politic.

Issues of integrity political participation among young people in social media are reported to have impacted aggressive action among rally supporters (Auvinen, 2012) where the use of social media to disseminate information among the participants of the demonstration events gathering, dissemination or seditious libel that could eventually lead to the country vulnerable to external attacks and threats (Malaysia, 2016; Al-Kandari \& Hasanen, 2012; Ayop, 2014).

This scenario reveals that the political participation among young people in social media without following the guidelines directly affects level of young people's integrity (Anon. 2015). Sharing wrong information (Harper \& Conversation 2017), give negative comments (Samuel-Azran Yarchi \& Wolfsfeld, 2017), causing chaos to gain popularity or viral (Edgerly et al. 2016) and eventually will lead to low level of integrity among young people (Muhammad, 2014). Media literacy competencies have been discussed as a control agent of human behaviour to curb low integrity movements as spreading fake news (Malaysia 2016), disseminating demonstration activity information among rally attendees (Al-Kandari \& Hasanen, 2012), spreading slander or sedition that could eventually expose the country to external attacks and threats (Ayop, 2014).

Media literacy is very important to readers, users and viewers of information or information from the media. Classic notion of media literacy refers to the ability to capture information and explain the meaning of information or actions in the media (Messaris, 1998). Enhancing media as a vehicle of disseminating information and feeding knowledge to the society, media literact reported as a core competency for engaged citizenship in democracy system (Thevenin, 2013). Political activities influence by social media not only drive young people towards low integrity actions but predisposed to civic engagement by utilizing media literacy as a core competency for integrity political participation among young people (Waller, 2013).

Social media use claimed by political scientist influenced low integrity level among young people (Young, 2014) but aligning political movements with media literacy competency (Eveland, 2000) develop civic engagement (Petter Bae Brandtzaeg, 2012) from civic knowledge (Ainley, 2013) and drive to democracy participatory (Guo, 2013). It is essential for young people actively engage in political activities having media literacy competency in developing critical thinking, high integrity content creator, effective communicator and act as social change agent in society. 
The focus of this paper is to provide psychometric analysis on new media literacy inventory in enhancing the integrity of political participation by using media literacy theoretical framework and this tool one of the important methods to develop media literacy competency among young people. This paper will also discuss on aspects of new media literacy such as access, analysis and evaluate, create, reflect and act (Koc \& Barut, 2016) influence moral actions and movements in political activities. This means that the main function of media literacy in the field of communication is to improve communication skills with integrity in society and not be fooled by the content in the media. Therefore, this study argues that to prevent and strengthen the integrity of the political participation of young people in social media, media literacy is expected to produce the idea of strengthening the implementation of the integrity of the political participation of young people in social media.

\section{Media Literacy and Political Participation}

With a complex media environment and data-rich media literacy skills are essential. The importance of media literacy is also to produce critical users who are not only receive the information but also critically analyze it. Through the development and advancement of media technology has produced a variety of data and information. The process of communication and information received among the public has also changed online. But the diversity of the information needs to be filtered and analyzed critically by its users in order to get accurate and valid information. Technical skills and critical thinking are needed to evaluate and analyze media content.

While the use of new media is an effective means of obtaining information, it can also lead to abuse and cybercrime. According to a statement issued by the country's Inspector-General of Police, Tan Sri Mohamad Fuzi Harun, with digital technology supported by access to the world of social media without boundaries, it has contributed to a wide range of commercial crime trends, especially cybercrime (Mokhtar, 2018). These cybercrimes include slandering to the leaders of the country, undermining the royal system and federal constitution that finally leads to moral collapse, political instability, social and national sovereignty.

The concept of media literacy is a skill that requires the ability to critically handle and process media messages, create and disseminate through traditional and new media channels (Ciurel, 2016). Media Literacy is a field and movement that facilitates and promotes critical thinking skills oriented to media messages. This capability needs to be strengthened to help reduce or prevent user from content risk, personal information risk and behavioral risk.

Digital media users must empower themselves with certain skills to become well-versed digital media literacy. Many researchers point out that media literacy skills are the ability to understand, analyze, and evaluate online information and online news (Burroughs et al. 2009; Kim, \& Yang, 2016; Martens, \& Hobbs, 2015; Rivoltella, 2009), communication skills (ability to find, store, share, create and evaluate information), critical thinking, risk awareness and online opportunities, creative activities and the ability to produce content by using digital media tools in innovative ways (Rivoltella 2009), or to discuss political issues (Kahne, Lee \& Feezell, 2012).

In the new media, consumers are also publishers of media content (Papacharissi, 2010) especially young activists (Lee, \& Ting, 2015). In addition, digital media interactions can support young people to be a source of information and at the same time informative (Flanagin, \& Metzger, 2008). Many people are able to produce their own games, music, news, and videos whereas before 
the advent of the new media this ability was only held by media professionals (Bennett 2008; Flew 2014). Given the low cost of digital publishing tools, it provides the opportunity for ordinary people to produce and distribute from start-up to content development (Flew 2014). According to (Flew 2014) media literacy is not just a matter of interpretation or contextual awareness but it is a series of digital production skills that include creative skills, critical skills in using and contributing media content.

Furthermore, Jenkins et al. (2009) explain that new media literacy is a social and cultural skill developed online, and is based on basic literacy, such as reading and writing, research skills, and critical media analysis skills. In addition, Martens and Hobbs (2015) added that critical reading and writing skills in the digital media era are important in order to enhancing the critical reading and writing skills of young people in analyse content. Effective digital media literacy programs and continuous learning for civic participation should be provided. All of these are digital media literacy skills needed as active citizens in a democratic society for full participation in social and political activities.

This digital literacy gives individuals the ability to live, learn, work, and participate as digital citizens. However, the Australian Communication Media Authority (ACMA) states that digital media literacy is a term to different interpretations such as the ability to understand and use information in a variety of formats from various sources when presented via computer (Gilster, 1997), skills, knowledge and understanding that enable users to use media effectively and safely (European Commission, 2009); and the ability to use, understand and create communication in multiple contexts (Australian Communication Media Authority, 2009).

Media literacy skills include, access and retrieval, analysis and evaluation, communication and creation, reflect and action (Renee Hobbs 2010; Kahne et al. 2012; Lin et al. 2013) and these skills are important and urge users in the digital age. For the purpose of this study, media literacy is used for the ability to use, analyse and evaluate, and make information online through digital media as suggested by Hobbs (2010), for all aspects of life, people today require advanced communication configuration and problem solving skills encompassing five digital media competencies namely access, analysis and evaluate, create, reflect and act.

There has been a shift in how people define new media literacy that moves from individual expression to community participation (Jenkins et al. 2009) and public participation (Rheingold 2008). As new media literacy provides people with a background in media, such as their audience, their impact, their institutions and their messages (Burroughs et al. 2009; Martens, \& Hobbs 2015), and also allows society to use all types of digital media to voice and share their views (Simsek, \& Simsek 2013). In addition, the most important part of new media literacy in relation to civic and political processes is the approach to participation. This is because, today, digital media technology has become a fundamental element of civic and political life, especially for young people (Bennett 2008; Kahne et al. 2012; Simsek, \& Simsek, 2013).

Media literacy can foster public participation especially young people as they have direct experience through online lectures, discussions, publications, and collective action (Rheingold, 2008). Media literacy has become a tool for analysing the ability of young people to participate in civic engagement and political participation to support the institutions and practices of democracy in Malaysia. 
The link between media communication and politics has a close relationship as it is the medium of information for community and government. A very important role should be taken in the field of media communication in Malaysia to provide critical education and skills that can act as a medium of integration and awareness as well as a deterrent to immoral behaviour and acts of community. With the freedom given to the public to communicate freely it is difficult to contain the negative symptoms using new media. But new media literacy is an effective way to nurture and educate from the very beginning such as primary and secondary education should be strengthened to provide digital citizens with full integrity and moral values.

Generally, it is difficult for the authorities to eradicate the symptoms of immorality as Internet users in Malaysia have almost 30 million people and they can open more than one social media account under different names. In addition, when misconduct has occurred the authorities need to devote a lot of time to tracking down the individual who first made the statement or made the offense.

\section{Access Competency}

An access aspect is the ability to find and share information with the public using the tools provided (Hobbs, 2010). This includes updating personal profiles (Paulussen et al. 2010), sending and sharing information with other social media users (Maamari \& Zein, 2014). In addition, assessing the relationship of access aspects with political participation is also given attention to the information seeking skills through search applications (Koltay, 2011).

Study of media literacy by Buckingham (2005) on young people suggests that media literacy education should be a strategy to encourage public to use media wisely instead of blocking and censorship. Some of the emphasis is on access aspects that impact negative behaviour on media users.

According to Buckingham (2005) access aspect affects consumers as a result of information gained through new media and it is also an important aspect of addressing social inequalities (Lee et al. 2013). However, according Multiple Access Model by Dijk's (2005), one must have media access skills before they can use the media. The differences in usage can be explained by the level of digital skills of the community (Deursen, \& Dijk, 2008). This ability to access is not only effects on one's self, mentality and emotions but also affects one's actions

\section{Analysis and Evaluate Competency}

According to Hobbs (2010) analysis and evaluate competency refer to user who are mentally critical; practice message composition and creativity; the ability to engage in ethics. When someone have media and digital literacy they will recognize the rights of others, their corporate, cultural and political agendas and exercise their right to speak on the basis of integrity (Aufderheide, 1993; Hobbs, 2010).

This aspect of analysis and evaluate is considered an important medium of media literacy because through media other than consumers, young people can act as producers of media content especially on social media. As such, many researchers in the fields of psychology, sociology, liberal media and socio-politics argue that the main goal of media literacy is to measure media use and the ability to analyze information in the media (Eristi \& Erdem, 2017). After accessing media content, a set of competencies such as analysis and evaluation is required. These competencies include the 
ability to analyze information sources and evaluate information sources from multiple sources (Lewis, \& Jhally, 1998).

This analysis and evaluate also refers to the ability to understand information and critical thinking on information sources as well as the ability to compare information from different sources (Mohd Sufiean et. al). In addition, this aspect of analysis and evaluate measures the ability of young people to seek political information and to ensure that it has integrity that is authentic, accurate and ethical and moral in nature (Hobbs, 2010).

Aspects of analysis and evaluate become more important to young people as technology adoption is faster than the adults and the interest in exploring technology applications directly improves access to information and thus leads to the aspects of analysis and resource evaluation (Lee 2005). In addition to the age factor, young people's education level is an indicator of their ability to analyze and evaluate sources of information to obtain accurate and valid information.

This idea was supported by Arsenijević, \& Andevski (2016) who conducted media literacy studies on the academic community in Serbia found that the level education in the field of education plays a major role in the field of information analysis and evaluate, where the technical-technology field has more analytical and higher information rating rather than social science. However, science social fields also contribute to the aspects of analysis and evaluate, in which the cognitive and psychomotor skills implemented in the syllabus directly generate critical thinking (Persson, 2013).

The value of integrity is achieved through the comparative quality of political information (Wolfsfeld et al., 2015), where political information positively impacting civic activity in society (Trenz, 2014), strengthens the practice of national democracy (Chang, 2017) and belief in the political system (Kee, 2009), where this value of trust refers to (1) the integrity and efficiency of the leadership system, (2) the efficiency and moral value of coping with political pressures, and (3) prioritizing responsive actions to the people (Carlin, 2014).

However, previous studies also reported that political information especially news on social media had higher levels of provocative political information rather than conventional media such as Television, Radio and Newspapers because political information on social media was not edited as a public reading, so it contained provocative information, slander and political sensation issues that are not reported in conventional media (Sufiean, Nurshahidah, Zuliani, \& Hanapi, 2013).

\section{Create Competency}

According to Kahne et al. (2012) aspect of create is the ability to generate and compose content by using creativity in capturing ideas to share with digital citizens. This aspect also gives young people the opportunity to voice out their views and share information by creating media content about politics from the perspective of young people in various forms. This is in line with Hobbs's (2010) idea of the creative aspect, which is an initiative to create media content in a variety of forms and formats.

This aspect of create is vital technical aspect for individuals to produce media content. This skill helps individuals create and produce media content such as video clips, pictures, and text easily and effectively. The Finland Ministry of Education emphasized the aspect of media content creation as it is more interactive and able to provide insights and meanings to be created (Commission, 2010). Thus, with a good understanding of the media content production will be more efficient and prudent, especially in issues related to political participation. 
This aspect is important because it reduces the cost for users to create content in a digital environment. Thus, the production of political information is easy, fast, and low-cost. Through social media platforms, users can easily provide, distribute and disseminate messages. In fact, according to Casero-Ripollés (2017) it gives people more space to create their own content rather than ever before which is only monopolized by the elite. With this competency can help strengthen democracy and facilitate greater participation in the public sphere.

\section{Reflect Competency}

According to Hobbs's (2010) white-paper paper and media literacy, media literacy encompasses skills such as emotional thinking, and social skills in the use of technology. In fact, according to Koc, \& Barut (2016) these skills include the ability to respond ethically which leads to critical use of the media by considering the effects behind such reactions. Identifying these skills can help them to solve problems, express their views and rights in accordance with ethical principles, social and legal responsibilities (Koc, \& Barut, 2016).

Reflect to media literacy is also a matter of receptiveness, culture, emotional intelligence, and morale. Therefore, there is definitely a difference between the reactions of the people of one country to another because it is based on their customs and culture. Viewed media content can determine a reaction. A media content published on an entertainment social media site cannot have the same effect if it is compared to political media content. This is because of the consideration of the potential risks and dangers of media messages and to understand how differences in values and life experiences shape media use and the interpretation of their messages.

The life cycle of the hierarchy of society plays a key role in deciding one's perception and understanding. Through reflect competency, one can enhance his or her ability to receive information in a broader and critical perspective space and reflect their actions (Schofield, 2014). Thus, according to Hobbs (2010) the reflect aspect must be accompanied by one's ability to understand the concept of privacy and the public as well as to respect and respect legal rights and responsibilities (copyright, intellectual freedom). It is important to know that communication can maintain the status quo, bring down a government and change the world.

According to Nupairoj (2016) reflect help individuals make more moral and ethical judgments when they create content and media information. This is in line with James Potter's (2008) theory that one must have social responsibility and internal integrity that can be used for the good of self and others. The skill is also to learn how a person's personal decisions affect society and his or her contribution to a particular community's actions. It is in line with the purpose of media literacy to educate users to systematically respond to understand and analyse their own experiences as readers and writers (Martens, 2010).

\section{Act Competency}

Media literacy has enabled people to use media to communicate information, share ideas and news from other perspectives. With social media literacy people will be more aware of their actions whether they have a positive or negative impact. It will also enable them to better understand how to act and not be acted upon (Malik, 2008). 
Chen, Wu \& Wang (2011) in their study entitled Unpacking New Media Literacy stressed that new media literacy is crucial to generation of the 21st century to be able to engage and provide critical insights with a good understanding of social, economic, political and cultural contexts a community. In fact, according to them, individuals with these skills are capable of formulating their ideas and opinions, expressing their views and beliefs based on analysis and evaluation made on various media sources.

According to Mihailidis, \& Thevenin (2013) the development of prudent participation skills begins with daily activities online. It has a strong impact on their behaviour and because many social media users are young people and it is possible that acts of infidelity can emerge.

\section{Research Methodology}

The respondents of this study were 388 Higher Education Institutions (HEI) students comprising four universities in Melaka, Malaysia. Student selection was based on random sampling. This study use questionnaires as a means of collecting data. Based on the number of respondents $(n=388)$ with complete data in this study, the sample size is large enough for the use of Structural Equation Modelling (SEM) (Hair, Black, Babin \& Anderson, 2010). Before proceeding to the final data collection, pilot study to test the reliability of the instrument was conducted to ensure the consistency of the questionnaire. Cronbach Alpha's reliability coefficient for all four variables, above 0.70 , shows a good internal consistency (Hair et al., 2010).

The adapted instrument was reviewed by an expert and a pilot test was conducted to determine the validity of the items. The aim of this study is to identify indicators of media literacy scale using Exploratory Factor Analysis and to identify structural measurement model using Confirmatory Factor Analisis (CFA).

\section{Research Instrument}

The questionnaire consists of two parts used as the instrument of this study. Part A consists of general information on demographic variables such as gender, age, status, race, education and social media usage. Part B contains a media literacy scale adapted from Mustafa Koc dan Esra Barut (2016), then translated into Malay. The scale to measure media literacy is a well-established scale that has proven its reliability because it is widely used in past studies. Reliability cronbach alpha for all five media literacy are between $0.89-0.92$. The steady use of the scale actually helps in terms of the reliability of the scale in gaining information through the public (Babbie 2013). This scale contains 33 items and is measured using a seven-level interval scale of $1=$ strongly disagree to $7=$ strongly agree. This measurement scale measures access, analysis and evaluate, create, reflect and act. 
INTERNATIONAL JOURNAL OF ACADEMIC RESEARCH IN BUSINESS AND SOCIAL SCIENCES Vol. 10, No. 2, Feb, 2020, E-ISSN: 2222-6990 @ 2020 HRMARS

Table 1 : Dimension of Media Literacy and Cronbach Alpha

\begin{tabular}{|c|c|c|c|}
\hline $\begin{array}{l}\text { Dimension of } \\
\text { media literacy }\end{array}$ & Research Instruments & Operational Definition & $\begin{array}{l}\text { Cronbach } \\
\text { Alpha }\end{array}$ \\
\hline Access & $\begin{array}{l}\text { New Media Literacy Scale } \\
\text { (NMLS) Mustafa Koc dan } \\
\text { Esra Barut (2016) }\end{array}$ & $\begin{array}{l}\text { Access refers to individuals } \\
\text { should have the skills to access } \\
\text { political information efficiently } \\
\text { on social media networks (sign } \\
\text { ups, logins and sent messages) } \\
\text { and using social media } \\
\text { (uploading and downloading } \\
\text { videos, editing photos, etc.). }\end{array}$ & .92 \\
\hline $\begin{array}{ll}\text { Analysis } & \text { and } \\
\text { Evaluate } & \end{array}$ & $\begin{array}{l}\text { New Media Literacy Scale } \\
\text { (NMLS) Mustafa Koc dan } \\
\text { Esra Barut (2016) }\end{array}$ & $\begin{array}{l}\text { Analysis and evaluate refers to } \\
\text { the ability to determine whether } \\
\text { the content of political } \\
\text { information on social media is } \\
\text { ethical, moral, integrity by } \\
\text { comparing political information } \\
\text { from one source to another on } \\
\text { social media. }\end{array}$ & .92 \\
\hline Create & $\begin{array}{l}\text { New Media Literacy Scale } \\
\text { (NMLS) Mustafa Koc dan } \\
\text { Esra Barut (2016) }\end{array}$ & $\begin{array}{l}\text { Create refers to the activity of } \\
\text { creating an account and filling } \\
\text { out profile information, creating } \\
\text { interactive political content on } \\
\text { social media through up-to-date } \\
\text { and authentic data such as } \\
\text { statistics, archive documents. }\end{array}$ & .89 \\
\hline Reflect & $\begin{array}{l}\text { New Media Literacy Scale } \\
\text { (NMLS) Mustafa Koc dan } \\
\text { Esra Barut (2016) }\end{array}$ & $\begin{array}{l}\text { Reflect refers to the ability to } \\
\text { contribute to the field of } \\
\text { discussion on social media by } \\
\text { analyzing political issues from } \\
\text { different perspectives and } \\
\text { ignoring social media that } \\
\text { disseminates political } \\
\text { information in an immoral and } \\
\text { unethical manner. }\end{array}$ & .91 \\
\hline Act & $\begin{array}{l}\text { New Media Literacy Scale } \\
\text { (NMLS) Mustafa Koc dan } \\
\text { Esra Barut (2016) }\end{array}$ & $\begin{array}{l}\text { Act refers to the activity of } \\
\text { uploading legitimate political } \\
\text { information / news / articles to } \\
\text { share with netizens. Provides } \\
\text { positive and unbiased feedback } \\
\text { on negative, immoral, ethical, }\end{array}$ & .89 \\
\hline
\end{tabular}


INTERNATIONAL JOURNAL OF ACADEMIC RESEARCH IN BUSINESS AND SOCIAL SCIENCES Vol. 10, No. 2, Feb, 2020, E-ISSN: 2222-6990 @ 2020 HRMARS

\begin{tabular}{|l|l|l|l|}
\hline $\begin{array}{l}\text { Dimension of } \\
\text { media literacy }\end{array}$ & Research Instruments & Operational Definition & $\begin{array}{l}\text { Cronbach } \\
\text { Alpha }\end{array}$ \\
\hline & & $\begin{array}{l}\text { and politically incorrect entries / } \\
\text { comments on social media and } \\
\text { reports to social media for } \\
\text { misconduct. }\end{array}$ & \\
\hline
\end{tabular}

\section{Data Analysis}

The data were analyzed by using descriptive statistic to describe the respondent profile of the study and exploratory factor analysis (EFA) with IBM SPSS 22.0 software. Analyzing EFA is an important foundation for strengthening the construction of constructs (Schumacker \& Lomax, 2010). The main use of EFA is to reduce the number of items and to detect the relationship structure between items that make up the construct dimension (Hair et al., 2010). In this study, principal component analysis with varimax rotation is used to determine the number of components.

AMOS 21.0 software was used to perform Confirmatory Factor Analysis (CFA). The CFA aims to determine the number of items included in the constructs in parallel with what is stated in theory (Byrne, 2010). The accuracy of the CFA model matching is determined by a combination of at least one Absolute Fit Indices and one Incremental Fit Indices (Hu \& Bentler, 1999; Hair et al., 2010) and Parsimony Fit Indices (PFI) (Hair et al., 2010). The test on CFA is used to determine whether the tested model should be accepted or rejected. However, there is no specific rule that determines whether a compatibility index needs to be reported for a model (Hooper, Coughlan \& Mullen; 2008, Hair et al., 2010). The use of three or more compatibility indexes is sufficient to prove a model fit, without to report all existing fit indexes (Hair et al., 2010).

\section{Findings}

\section{Exploratory Factor Analysis (EFA), Media Literacy}

The Social Control Measurement Scale tested consists of four constructs: Attachment, Involvement, Belief and Commitment and 33 items. Kaiser-Meyer Olkin Measure of Sampling Adequacy (KMO) value $=0.942$ is above the value of $>0.6$ to meet the exploratory factor analysis (Hair et al., 2010; Pallant, 2007). While the value of Bartlett's Test is significant $(p<.05)$. This shows that the items used in the Exploration Factor Analysis of this study have good inter-correlation strengths with each other. Table 2 shows the result of Construct matrix correlation.

Table 2 : Media Literacy Correlations Matriks

\begin{tabular}{|c|c|c|c|}
\hline \multicolumn{3}{|c|}{ Kaiser-Meyer-Olkin Measure of Sampling Adequacy. } & .942 \\
\hline \multirow{3}{*}{$\begin{array}{l}\text { Bartlett's } \\
\text { Sphericity }\end{array}$} & Test of & Approx. Chi-Square & 9775.983 \\
\hline & & df & 528 \\
\hline & & sig. & .000 \\
\hline
\end{tabular}


INTERNATIONAL JOURNAL OF ACADEMIC RESEARCH IN BUSINESS AND SOCIAL SCIENCES Vol. 10, No. 2, Feb, 2020, E-ISSN: 2222-6990 @ 2020 HRMARS

According to Hair et al. (2010), items with low loading factor from 0.50 should be removed. In this study, all items accepted due to factor loading greater than 0.50, which are in between 0.523 to .978. To test convergent validity, researchers use Average Variance Extracted (AVE) and Construct Reliability (CR). According to Hair et al. (2010), the AVE value should be greater than 0.5 and CR is greater than 0.7. Based on AVE's decision for access, analysis and evaluate, create, reflect and act, these five constructs exceeded 0.5. The reliability value of all four latent variables (constructs) ranges from 0.866 to 0.925 , greater than 0.70 , shows that Cronbach's alpha is in good condition. The discriminant validity is to measure one construct with another construct and should not have a high correlation. Byren (2010) suggests that the value of $r=0.90$ or more indicates that the variable has a high correlation. Since the correlation findings in Table 3 show values in between 0.785 to 0.831 , this means that there is no high correlation problem (multicollinearity).

Table 3: Average Variance Extracted, Constructs Reliability and Correlation

\begin{tabular}{|c|c|c|c|c|c|c|c|c|}
\hline $\begin{array}{l}\text { Latent Variable } \\
\text { (Constructs) }\end{array}$ & CR & AVE & A & Access & $\begin{array}{l}\text { Analysis } \\
\text { and } \\
\text { Evaluate }\end{array}$ & Create & $\begin{array}{l}\text { Reflec } \\
t\end{array}$ & Act \\
\hline Access & 0.866 & 0.620 & 0.968 & 0.787 & & & & \\
\hline $\begin{array}{l}\text { Analysis and } \\
\text { Evaluate }\end{array}$ & 0.925 & 0.639 & 0.930 & 0.612 & 0.800 & & & \\
\hline Create & 0.902 & 0.647 & 0.958 & 0.435 & 0.641 & 0.805 & & \\
\hline Reflect & 0.887 & 0.616 & 0.980 & 0.301 & 0.548 & 0.791 & 0.785 & \\
\hline Act & 0.899 & 0.690 & 0.975 & 0.285 & 0.529 & 0.725 & 0.886 & 0.831 \\
\hline
\end{tabular}

Note: $\mathrm{AVE}=$ Average Variance Extracted, $\mathrm{CR}=$ Contsruct Reliability, $\alpha=$ Cronbach Alpha

Table 4 : Factor Loading Hypotheses to Constructs Indicators

\begin{tabular}{llll}
\hline \multicolumn{2}{c}{ Indication } & Construct & $\begin{array}{l}\text { Statistik } \\
\text { Loading }\end{array}$ \\
\hline AK1 & $\leftarrow$ & Access & $.906^{* * *}$ \\
AK2 $\leftarrow$ & Access & $.961^{* * *}$ \\
AK3 $\leftarrow$ & Access & $.947^{* * *}$ \\
AK4 $\leftarrow$ & Access & $.873^{* * *}$ \\
AK5 & $\leftarrow$ & Access & $.535^{* * *}$ \\
AK6 & $\leftarrow$ & Access & $.824^{* * *}$ \\
AK7 & $\leftarrow$ & Access & $.562^{* * *}$ \\
AP1 & $\leftarrow$ & Analysis and Evaluate & $.929^{* * *}$ \\
AP2 & $\leftarrow$ & Analysis and Evaluate & $.974^{* * *}$ \\
AP3 & $\leftarrow$ & Analysis and Evaluate & $.963^{* * *}$ \\
AP4 & $\leftarrow$ & Analysis and Evaluate & $.819^{* * *}$ \\
AP5 & $\leftarrow$ & Analysis and Evaluate & $.862^{* * *}$ \\
AP6 & $\leftarrow$ & Analysis and Evaluate & $.832^{* * *}$ \\
AP7 & $\leftarrow$ & Analysis and Evaluate & $.821^{* * *}$ \\
PC1 & $\leftarrow$ & Create & $.523^{* * *}$ \\
\hline
\end{tabular}


INTERNATIONAL JOURNAL OF ACADEMIC RESEARCH IN BUSINESS AND SOCIAL SCIENCES Vol. 10, No. 2, Feb, 2020, E-ISSN: 2222-6990 @ 2020 HRMARS

\begin{tabular}{rlll}
\hline PC2 & $\leftarrow$ & Create & $.598^{* * *}$ \\
PC3 & $\leftarrow$ & Create & $.906^{* * *}$ \\
PC4 & $\leftarrow$ & Create & $.957^{* * *}$ \\
PC5 & $\leftarrow$ & Create & $.716^{* * *}$ \\
PC6 & $\leftarrow$ & Create & $.864^{* * *}$ \\
PC7 & $\leftarrow$ & Create & $.827^{* * *}$ \\
TB1 & $\leftarrow$ & Reflect & $.927^{* * *}$ \\
TB2 & $\leftarrow$ & Reflect & $.649^{* * *}$ \\
TB3 & $\leftarrow$ & Reflect & $.974^{* * *}$ \\
TB4 & $\leftarrow$ & Reflect & $.796^{* * *}$ \\
TB5 & $\leftarrow$ & Reflect & $.978^{* * *}$ \\
TB6 & $\leftarrow$ & Reflect & $.964^{* * *}$ \\
TK1 & $\leftarrow$ & Act & $.945^{* * *}$ \\
TK2 & $\leftarrow$ & Act & $.978^{* * *}$ \\
TK3 & $\leftarrow$ & Act & $.898^{* * *}$ \\
TK4 & $\leftarrow$ & Act & $.846^{* * *}$ \\
TK5 & $\leftarrow$ & Act & $.941^{* * *}$ \\
TK6 & $\leftarrow$ & Act & $.949^{* * *}$ \\
\hline ized Regression Weights significant level at the .001 (2 tailed)
\end{tabular}

Based on Table 4, all loading factors are significant at the level of 0.001 and above 0.5 for all indicators. In addition, high standard regression values (0.523 to 0.978$)$ indicate that all measured indicators are significantly representing their latent variables - constructs.

\section{Confirmatory Factor Analysis (CFA) Media Literacy}

Model specifications include 33 items, seven items for access, seven items for analysis and evaluate, seven items for create, six items for reflect and six items for act. However, this model should be modified in order to improve the fit of this model represents the sample data or real data better. Modifications are made by reference to the modification index. As a result, items AK1 (.46), AK7 (.48), PC1 (.47), PC2 (.38), TK5 (.42) and TK6 (.41) in the model had to be removed due to low loading factors $<0.5$. Next, items with high Modification Indice (MI) and high correlation between the two items were also modified. According to Hair et al. (2014), if there is a high correlation between the two items, they can be combined to obtain a model fit. Whereas if the item is not theoretically supported, the model needs to be modified by removing either one items with lower factor loadings (Hair et al. 2014).

The measurement model in Table 5 shows a good data fit with eight indicators ie ( $\chi 2$, CMINDF, RMSEA, GFI, IFI, TLI, CFI and PGFI) as shown in Table 5. However, Marsh \& Hau (1996) Chi-square (X2) can be divided by degrees of freedom $(\mathrm{df}=100)$ to evaluate model fit compared to using $\chi 2$ (CMINDF). If the CMINDF statistics count is less than the value of 5 , the fit of the data for the validation factor model is good (Marsh \& Hau, 1996). CMINDF for this measurement model is less than the value of 5 (CMINDF $=2.250$ ). This shows a fairly good CFA model. Furthermore, the RMSEA value is 0.057 which is lower than .08 as suggested by Kline (2010). The index coefficients in Table 5 are all greater than 
INTERNATIONAL JOURNAL OF ACADEMIC RESEARCH IN BUSINESS AND SOCIAL SCIENCES

Vol. 10, No. 2, Feb, 2020, E-ISSN: 2222-6990 @ 2020 HRMARS

0.90 show a good model fit (Byrne, 2010), and the PGFI value is greater than 0.5 (.700) which also shows a good model fit with data (Hair, et al., 2010). Fifteen (15) items have been combined due to the high index value of the modification (M.I). Figure 1 shows the CFA Model for this study.

Table 5: Confirmatory Factor Analysis (CFA)

\begin{tabular}{lllllllll}
\hline Description & $\chi^{2}$ & CMINDF & RMSEA & GFI & IFI & TLI & CFI & PGFI \\
\hline Model CFA & 573.785 & 2.250 & 0.057 & 0.892 & 0.956 & 0.948 & 0.956 & .700 \\
\hline
\end{tabular}

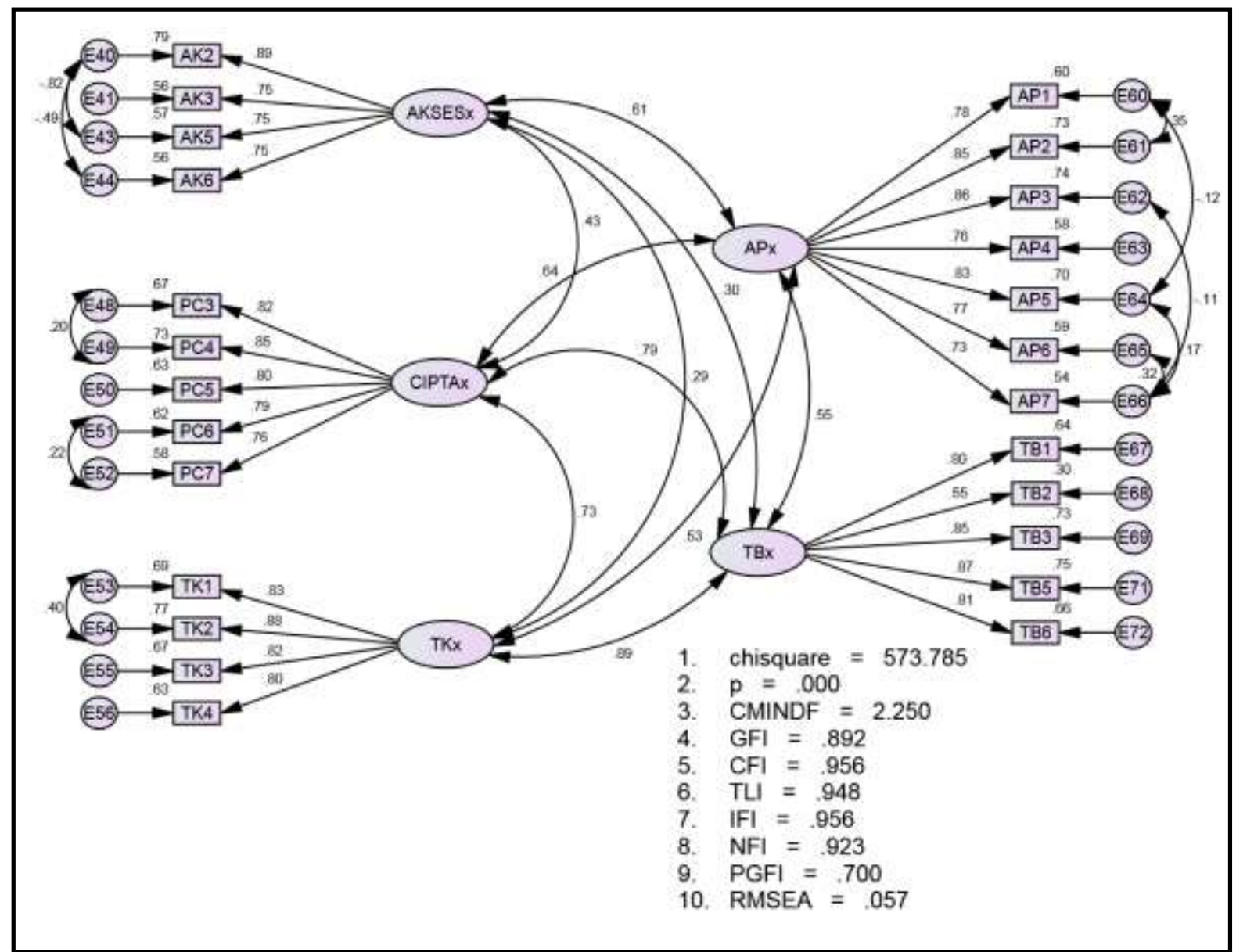

Figure 1: $\quad$ Confirmatory Factor Analysis Model of Media Literacy

\section{Discussion}

Findings show that multi-dimensional models of media literacy scales have achieved good model fit and achieve convergence validity based on significant relationship variables. This scale also achieves discriminant and predictive validity that supports the psychometric characteristics of the Malay version. The confirmatory factor analysis model (CFA) with construct validity also illustrates that the constructs of access, analysis and evaluate, create, reflect and act in the essential competencies of 
INTERNATIONAL JOURNAL OF ACADEMIC RESEARCH IN BUSINESS AND SOCIAL SCIENCES

Vol. 10, No. 2, Feb, 2020, E-ISSN: 2222-6990 ¿ 2020 HRMARS

digital and media literacy have been valid tested to represent their respective constructs. However, this scale is limited to measuring young people who actively use social media.

\section{Conclusion}

The main focus of this study is to identify the psychometric characteristics of the aspect of validity and reliability of the scale of media literacy adapted from the scale Mustafa Koc dan Esra Barut (2016). The need to translate this scale into Malay is to open the study space to understand and measure the level of media literacy among Malaysians. This should be done because the measurement of media literacy has attracted Western researchers(Livingstone 2004; Martens, \& Hobbs 2015) which must be followed by Malaysia to benefit from the use of this media more effectively and with integrity.

\section{Corresponding Author}

Dr. Mohd Sufiean Hassan is a lecturer at Department of Communication, Faculty of Social Science, Kolej Universiti Islam Melaka, Malaysia (KUIM). Email: sufiean@kuim.edu.my.

\section{References}

Al-Kandari, A., \& Hasanen, M. (2012). The impact of the Internet on political attitudes in Kuwait and Egypt. Telematics and Informatics, 29(3), 245-253.

Ana Radovic, T. G. (2017). Depressed adolescents' positive and negative use of social media. Journal of Adolessence, 5-15.

Anom, E., Kee, C. P. \& Zawawi, J. W. M. (2014). Political discourse in Indonesia and Malaysia for national human security: A case study of Lahad Datu. Jurnal Komunikasi, 30(2), 183-200.

Anon. (2015). Kemajuan teknologi landasan sebar fitnah tanpa sedar. Berita Harian Online, http://www.bharian.com.my/node/92875 [4 June 2016].

Aufderheide, P. (1993). Media Literacy: A Report of the National Leadership Conference on Media Literacy. Media literacy in the Information age current perspectives, hlm.Vol. 6.

Australian Communication Media Authority. (2009). Digital media literacy in Australia: key indicators and research sources. Australian Communication Media Authority, http://www.acma.gov.au/theACMA/digital-media-literacy-in-australia-key-indicators-andresearch-sources [26 June 2018].

Auvinen, A. (2012). Social media - The new power of political Influence. Centre for European Studies, 1-16.

Babbie, E. (2013). The Practice of Social Research hlm.13th Edisi. Canada: Wadsworth, Cengage Learning.

Baran, S. (2014). Introduction to mass communication: Media literacy and culture. New York: McGraw Hill.

Bennett, W. L. (2008). Civic learning in changing democracies: Challenges for citizenship and civic education. DIm. Dahlgren (pnyt.). Young citizens and new media learninng for democratic participation, hlm.57-78. New York: Routledge.

Brian A. Primack, A. S. (2017). Social media use and perceived social isolation among young adults in the US. American Journal of Preventive Medicine, 1-8. 
INTERNATIONAL JOURNAL OF ACADEMIC RESEARCH IN BUSINESS AND SOCIAL SCIENCES

Vol. 10, No. 2, Feb, 2020, E-ISSN: 2222-6990 @ 2020 HRMARS

Buckingham, D. (2005). The Media Literacy of Children and Young People. Ofcom.

Burroughs, S., Brocato, K., Hopper, P. F. \& Sanders, A. (2009). Media literacy: A central component of democratic citizenship. Educational Forum, 73(2), 154-167.

Chen, D.-T. victor, Wu, J. \& Wang, Y. (2011). Title Unpacking new media literacy Unpacking New Media Literacy. Journal of Systemics, Cybernetics and Informatics, 9(2), 84-88.

Ciurel, D. (2016). Media literacy: Concepts, approaches and competencies. Professional Communication and Translation Studies, 9, 13-20

Commission, E. (2010). Approaches - existing and possible - to media literacy.

Dannagal, G., Young, R. L. (2014). Successful Practices for the Strategic Use of Political Parody and Satire: Lessons From the P6 Symposium and the 2012 Election Campaign. American Behavioral Scientist, $1111-1130$.

David, A., Cole, E. A. (2017). Online social support for young people: Does it recapitulate in person social support: Can it help. Computers in Human Behavior, 456-464.

Deursen, A. V. \& Dijk, J. V. (2008). Measuring digital skills: Performance tests of operational, formal, information and strategic Internet skills among the Dutch population. Paper presented at the 58th Conference of the international Communication Association.

Edgerly, S., Thorson, K., Bighash, L., \& Hannah, M. (2016). Posting about politics: Media as resources for political expression on Facebook. Journal of Information Technology and Politics, 13(2), 108-125.

Eristi, B. (2017). Development of a Media Literacy Skills Scale. Contemporary Educational Technology, $8(3), 249-267$.

Flanagin, A. J., \& Metzger, M. J. (2008). Digital media and youth: Unparalleled opportunity and unprecedented responsibility. DIm. M. J. M. and A. J. Flanagin (pnyt.). DigitalMedia, Youth, and Credibility, hlm.5-28. Cambridge, MA: The MIT Press.

Flew, T. (2014). New media: An introduction hlm.4th Edisi. Melbourne: Oxford University Press.

Foster M. L. (2014) Elements of a crime. The Encyclopedia of Criminology and Criminal Justice, 1-4

Gee, P. J. (2010). New digital media and learning as an emerging area and "worked examples" as one way forward. Cambridge: MIT Press.

Guo, M. C. (2013). The Role of Political Efficacy on the Relationship Between Facebook Use and Participatory Behaviors:. Cyberpsychology, Behavior, and Social Networking, 460-463.

Hafez, M. H. M. (2016). "Facebook" usage during election campaigns and its impact on voters' attitudes and decisions towards political candidates.

Hamzah, S. E. (2010). Media sosial: Tinjauan terhadap laman jaringan sosial dalam talian tempatan. Jurnal Pengajian Media Malaysia, 37-52.

Harper, C. (2017). Being more media savvy won't stop the spread of -fake news\|-here's why. https://phys.org/news/2017-05-media-savvy-wont-fake-newshere.html [23 November 2017].

Hayes, C. T. (2016). As social support: Relational closeness, automaticity and interpreting social support from paralinguistic digital affordances in social media. Computers in Human Behavior, 386-393.

Hinrichsen, J., \& Coombs, A. (2013). The five resources of critical digital literacy: A framework for curriculum integration. Research in Learning Technology, 21(1063519), 1-16. 
Hobbs, R. (2010). Digital and media literacy. Washington: The Aspen Institute.

Hyldegård, J. (2014). Young learners' use of social media for information seeking: Exploring core LIS Journals from 2010-2014. Library and Information Science Research e-journal, 108-117.

Ika Destiana, A. S. (2013). Penerimaan media sosial: Kajian dalam kalangan pelajar universiti di Palembang. Jurnal Komunikasi, 125-140.

Jenkins, H., Purushotma, R., Weigel, M., Clinton, K., \& Robison, A. J. (2009). Confronting the Challenges of Participatory Culture: Media Education for the 21st. Century, White Paper for MacArthur Foundation.

Ainley, J. W. S. (2013). Attitudes towards political engagement among lower secondary students in East Asian countries: Results from ICCS 2009. International Research Conference in Singapore (pp. 1-7). Singapore: IEA.

Kahne, J., Lee, N.-J. N. \& Feezell, J. T. (2012). Digital media literacy education and online civic and political participation. International Journal of Communication, 6(1), 1-24.

Kim, E. M., \& Yang, S. (2016). Internet literacy and digital natives' civic engagement: Internet skill literacy or Internet information literacy? Journal of Youth Studies, 19(4), 438-456.

Koc, M., \& Barut, E. (2016). Development and validation of New Media Literacy Scale (NMLS) for university students. Computers in Human Behavior, 63(October 2016), 834-843.

Koltay, T. (2011). The media and the literacies: media literacy, information literacy, digital literacy. Media, Culture \& Society, 32(2), 211-221.

Kumar, R., \& Thapa, D. (2014). Social media as a catalyst for civil society movements in India: A study in Dehradun city. New Media \& Society, 1461444814523725-.

Lee, A. Y. L., \& Ting, K. W. (2015). Media and information praxis of young activists in the Umbrella Movement. Chinese Journal of Communication, 8(4), 376-392.

Lee, A., Lau, J., Carbo, T., \& Gendina, N. (2013). Conceptual Relationship of Information Literacy and Media Literacy in Knowledge Societies. United Nations.

Lee, J. W. (2017). When does individuals' willing to speak out increase on social media. Perceived social support and perceived power/control. Computer In Human Behavior, 120-129.

Lee, L. (2005). Young people and the Internet. Young, 13(4), 315-326.

Lewis, J., \& Jhally, S. (1998). The struggle over media literacy. Journal of Communication, 48(1), 109120.

Lin, T., Li, J., Deng, F., \& Lee, L. (2013). Understanding New Media Literacy: An Explorative Theoretical Framework. Educational Technology \& Society, 16(4), 160-170.

Livingstone, S. (2004). Media literacy and the challenge of new information and communication technologies. Communication Review, 7(1), 3-14.

Maamari, B. E., \& Zein, H. E. (2014). The impact of social media on the political interests of the youth in Lebanon at the wake of the arab spring. Social Science Computer Review, 32(4), 496-505.

Malaysia. (2016). Laporan hak asasi manusia 2015. https://my.usembassy.gov/wpcontent/uploads/sites/30/2016/05/hrr-my2015-041316.pdf [7 Februari 2017]

Malik, S. (2008). Media Literacy and its Importance. Society for Alternative Media and Research.

Martens, H., \& Hobbs, R. (2015). How Media Literacy Supports Civic Engagement in a Digital Age. Atlantic Journal of Communication, 23(2), 120-137. 
INTERNATIONAL JOURNAL OF ACADEMIC RESEARCH IN BUSINESS AND SOCIAL SCIENCES

Vol. 10, No. 2, Feb, 2020, E-ISSN: 2222-6990 @ 2020 HRMARS

Martens, H. (2010). Evaluating Media Literacy Education: Concepts, Theories and Future Directions. Journal of Media Literacy Education, 2, 1-22.

Madden, M. A. L. (2017). Pew Research Center. Retrieved from http://www.pewinternet.org/2013/05/21/teens-social-media-and-privacy/.

MCMC. (2017). Internet users survey 2017. Putrajaya. Retrieved from http://www.mcmc.gov.my

Mohd Ayop Abd. Razid. (2014). Jenayah siber isu mencabar. Mentari, 8-9.

Sufiean, M. H., Nurshahidah, S. A., Hanapi, M. K., Hilmi, M. B., Imma, D. A. L., \& Rauf, A. H. R. (2019). Perspektif Literasi Media Aspek Analisis dan Penilaian: Amalan Integriti Penyertaan Politik Golongan Muda di Media Sosial. Jurnal Sains Sosial, 1 (1), 20-32.

Sufiean, M. H., Nurshahidah, S. A., Zuliani, M. A., \& Hanapi, M. K. (2013). Social Media and Political Participation among Young People. Jurnal Sains Sosial, 1(1), 95-114.

Abdullah, M. (2014). Generasi baharu wajar dipupuk integriti, etika. Berita Harian Online,. http://www.bharian.com.my/node/23078 [1 June 2016].

Nupairoj, N. (2016). The ecosystem of media literacy: A holistic approach to media education. Comunicar, 24(49), 29-37.

Omar, F. I. (2014). Penerimaan media sosial sebagai medium dakwah dalam kalangan mahasiswa KUIS. E-proceedings of the Conference on Management and Muamalah, 1-11.

Papacharissi, Z. (2010). A Private Sphere: Democracy in a digital age. Cambridge: Polity Press.

Patton, D. U., Hong J. S., Ranney M., Patel S., Kelley C., Eschmann R., Washington T. (2014). Social media as a vector for youth violence: A review of the literature. Computers in Human Behavior

Messaris, P. (1998). Visual Aspects of Media Literacy. Journal of Communication. 70-80

Paulussen, S., Courtois, C., Mechant, P. \& Verdegem, P. (2010). Adolescents' new media literacy in flanders (Belgium). Observatorio (OBS*), 4, 361-374.

Pérez Tornero, J. M., \& Varis, T. (2010). Media literacy and new humanism. Moscow: UNESCO Institute for Information Technologies in Education.

Petter Bae Brandtzaeg, A. F. (2012). Designing for youth civic engagement in social media. International Conference of Social Media and Web Based Communities, 1-8.

Plotkowiak, T. (2014). The influence of social capital on information diffusion in Twitter's interestbased social networks (4231), 280.

Rheingold, H. (2008). Using participatory media and public voice to encourage civic engagement. DIm. Bennett (pnyt.). Civic Life Online: Learning How Digital Media Can Engage Youth, hlm.97-118. The John D. and Catherine T. MacArthur Foundation Series on Digital Media and Learning. Cambridge, MA: The MIT Press.

Rivoltella, P. C. (2009). Constructive Controversies within Media Literacy. DIm. Verniers (pnyt.). Media Literacy in Europe Controversies, Challenges and Perspectives, hlm.43-47. Hershey, PA: IGI Publishing. Retrieved from http://www.euromeduc.eu/IMG/pdf/Euromeduc_ENG.pdf

Salman, A., Ibrahim, F., Abdullah, M. Y. H., Mustaffa, N., \& Mahbob, M. H. (2011). The impact of new media on traditional mainstream mass media. Innovation Journal, 16(3), 2-11.

Samuel-Azran, T., Yarchi, M., \& Wolfsfeld, G. (2017). Engagement and likeability of negative messages on facebook during Israel's 2013 elections. The Journal of Social Media in Society, 6(1), 42-68.

Schofield, D. (2014). Young people exploring their media experiences - mediagraphy as a reflection tool in upper secondary school. Nordic Journal of Digital Literacy, 9(2), 112-127. 
Simsek, E., \& Simsek, A. (2013). New Literacies for Digital Citizenship. Contemporary Educational Technology, 4(2), 126-137.

Thevenin, P. M. (2013). Media Literacy as a Core Competency for Engaged Citizenship in Participatory Democracy. American Behavioral Scientist, 1611-1622.

Dijk, V. J. A. G. M. (2005). The deepening divide: inequality in the information society. Communication.

Waller, L. G. (2013). Enhancing Political Participation in Jamaica: The Use of Facebook to "Cure" the Problem of Political Talk Among the Jamaican Youth. SAGE Open, 1-9.

William, P., Eveland, J. (2000). Connecting News Media Use with Gaps in Knowledge and Participation. Political Communication, 215-237. 
INTERNATIONAL JOURNAL OF ACADEMIC RESEARCH IN BUSINESS AND SOCIAL SCIENCES

Vol. 10, No. 2, Feb, 2020, E-ISSN: 2222-6990 ¿ 2020 HRMARS

Appendix: Item Media Literacy

\section{Access}

No Item

Statistic

Loading

1 I'm good in accessing social media networks (sign ups, logins and sent .906*** messages).

$2 \quad$ I'm good in using social media tools.

3 I'm good in using social media (uploading and downloading videos, editing .947*** pictures, etc).

$4 \quad$ I'm good in using search applications to find information on social media.

$.873 * * *$

$5 \quad$ I am able to use various social media to find political information.

$.535 * * *$

6 I can access to social media based on my needs and goals such as .824*** communicating, finding friends, and playing online games.

7 I am able to identify my thoughts and views on political issues on social media. . $.562 * * *$

\section{Analysis dan Evaluate}

\begin{tabular}{llc}
\hline No & Item & $\begin{array}{l}\text { Statistic } \\
\text { Loading }\end{array}$ \\
\hline 1 & $\begin{array}{l}\text { I am able determine whether the content of political information on social } \\
\text { media is moral or immoral. }\end{array}$ \\
2 & $\begin{array}{l}\text { I am able to compare political information from one source to another on } \\
\text { social media. }\end{array}$ \\
3 & $\begin{array}{l}\text { I am able to compare information on social media with my own political } \\
\text { understanding. }\end{array}$ & $.963^{* * * *}$ \\
4 & $\begin{array}{l}\text { I consider using social media with high volume of likes, comments, shares. } \\
5\end{array}$ & $\begin{array}{l}\text { I am able to make decisions on the validity and accuracy of political } \\
\text { information on social media. }\end{array}$ \\
6 & $\begin{array}{l}\text { I was able to analyze the negative effects (fraud, slander, seduction) of using } \\
\text { political information sources on social media. }\end{array}$ & $.832^{* * * *}$ \\
7 & $\begin{array}{l}\text { I am able to evaluate social media that is ethical, moral and integrative in } \\
\text { disseminating political information. }\end{array}$ & $.821^{* * *}$
\end{tabular}

\section{Create}

No Item

Statistic

Loading

1 It is easy for me to create an account and fill out profile information on social $\quad .523 * * *$ media.

2 I am able to create interactive media content (text, audio, video) on social .598*** media.

3 I am good in sharing political information on social media with other users. $.906 * * *$ 
INTERNATIONAL JOURNAL OF ACADEMIC RESEARCH IN BUSINESS AND SOCIAL SCIENCES

Vol. 10, No. 2, Feb, 2020, E-ISSN: 2222-6990 ¿ 2020 HRMARS

4 I am able to provide opinions, comments and ideas from political information .957*** shared by other social media users.

5 I use sources of information on social media to generate opinions, comments .716*** and ideas for other social media users.

6 The data obtained such as statistics, archival documents and factual numbers on social media helped me to produce up-to-date / authentic political information.

7 I am produce ethical information / news / articles as the importance of source $.827^{* * *}$ validity.

\section{Reflect}

No Item

1 I am able to contribute to the field of discussion on social media by analyzing $.927^{* * *}$ political issues from different perspectives.

2 I make sure that posting information / news / political articles does not clash .649*** with religious teachings.

3 I ignore social media that disseminates immorally and unethically political $.974^{* * *}$ information.

4 Social media news / news / articles on social media increased my tendency to participate in political activities online (online forums, discussions with political leaders).

5 Social media news / news / articles on social media increased my tendency to engage in political activities (attending political talks, campaigns, conferences etc.)

6 I ignore unauthorized information / news / political articles from being shared .964*** with netizens. 
INTERNATIONAL JOURNAL OF ACADEMIC RESEARCH IN BUSINESS AND SOCIAL SCIENCES

Vol. 10, No. 2, Feb, 2020, E-ISSN: 2222-6990 @ 2020 HRMARS

Act

No Item $\quad$ Statistic

1 I am upload authentic political information / news / articles to share with .945*** netizens.

2 I will respond positively to negative comments / comments on political issues .978*** on social media.

3 I do not share, comment or like to immoral, unethical, and politically incorrect $.898 * * *$ information shared by other social media users.

$4 \mathrm{I}$ am able to interact with other social media users to discuss political issues. $.846 * * *$

$5 \mathrm{I}$ am joining an entry discussing political issues or scandals on social media. .941***

Correspondence: Dr. Mohd Sufiean Hassan, Communication Department, Faculty of Social Sciences, University College of Islam Melaka, Malaysia. 